\title{
Is a perfect storm brewing on the health care front?
}

Tn April, while Canadians 1 were speculating about the timing of an anticipated federal election, Ottawa embarked on a high-stakes gamble to bring medicare under closer federal control. To assess the magnitude - or wisdom - of this gamble, it may help to recall how we got to this point. When Mackenzie King's government tried to introduce a national health service after World War II, the constitutional assignment of health care to the provinces proved a barrier. (Earlier efforts by the Bennett adminstration to create national unemplyment insurance foundered on the same difficulty.) In the 1960 s, Lester Pearson found a solution: if the program were defined in sufficiently nonintrusive terms, it might be possible to avoid a court challenge. Consequently, all the Medical Care Act of 1966 said about the program's scope was that whichever primary and acute care services were "medically necessary" would be covered. In practical terms, this meant "whatever the provinces and physicians deem appropriate." Ottawa had signed a blank cheque to get universal health care off the ground.

This arrangement lasted until the 1984 blow-up over extra billing. To deal with the crisis, the federal government found a new way to side-step the constitutional roadblock. Ottawa argued that as a purchaser of health care services, it now had a consumer's right to choose which services it would purchase. And it chose not to purchase services from provinces that allowed extra-billing. The new Canada Health Act introduced a withholding mechanism to penalize $\checkmark$ jurisdictions that allowed the practice. As a sop to provincial sensitivities, the original language of "medically necessary" services was maintained.

Statutorily, that is where things remain. However, in recent years the threat to withhold funding has been rendered impotent by cutbacks in federal transfers - indeed, Ottawa hints it may abandon this form of coercion. More important, the intentionally vague language of the statute is now blamed for some of the dysfunctionality plaguing medicare.

Critics argue that, by failing to specify which services are covered, the Canada Health Act has fostered a patchwork of services unworthy of a national program. ${ }^{1}$ More troubling, a vacuum has been created that the courts are now beginning to occupy. Recent decisions in Nova Scotia, ${ }^{2}$ Quebec $^{3}$ and British Columbia ${ }^{4}$ raise the spectre of US-style litigation, driven by aggrieved patients' rights groups and greedy trial lawyers.

The provinces, which pay $80 \%$ of the costs, also point out that health spending has increased $500 \%$ in the last 25 years. They note that cardiac bypass surgery, cataract replacement, kidney transplants and hip replacements have been included in the growing list of "medically necessary" treatments. So have CT scans, ultrasound scanning and cholesterol testing. AIDS, SARS and the needs of a rapidly aging population have added to the burden. They complain that the openended nature of medicare's charter has given hostages to fortune.

In short, a powerful case can be made that medicare is unmanageable in its present form, and that a sharper definition of its scope and goals is needed.

Health Minister Pierre Pettigrew took up this challenge recently in Toronto. ${ }^{5}$ In a heavily nuanced speech, he reviewed the usual litany of woes besetting medicare - excessive wait times, inconsistent coverage, recurring crises. However, toward the end of his remarks, Pettigrew departed from previous federal positioning. He pointedly drew attention to the vague language of the Canada Health Act and dropped a bombshell. The time has come to rethink which services are included in medicare, he suggested:

[I]n recent years, differences of opinion as to how to interpret the Act's provisions, and inconsistent enforcement of its requirements, has resulted in growing confusion and uncertainty as to what the Act does and does not allow.

While I am not suggesting that the Act be re-opened, I do believe we have a responsibility to clarify its practical meaning in today's terms.

And he hinted that if this cannot be done through negotiations, the federal government may indeed rewrite the statute:

Canadians expect us to be more than just a system bankroller or a silent partner: we are prepared to take the next step forward to become a full system partner, to share in the risk of maintaining and enhancing the system over time and in shaping its future.

Given that health care falls under the provinces' exclusive jurisdiction, how can Ottawa

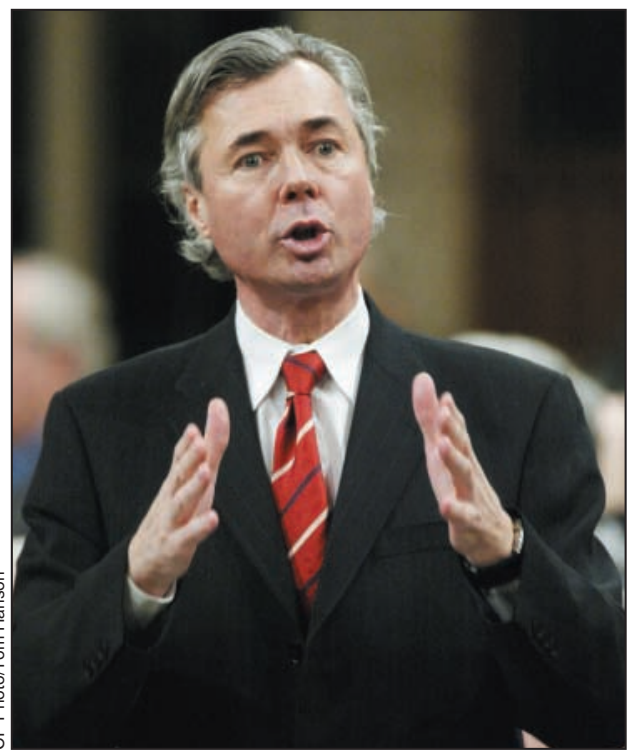

Health Minister Pierre Pettigrew: mixed messages or a high-stakes gamble? 
aim to become "a full system partner"? Well, in 2000 Health Canada negotiated an accord requiring the provinces to report on a common set of indicators in exchange for increased funding. Desperate for money, the provinces went along with this idea. In 2003 performance reporting was expanded to include mental health, home care, preand post-acute home care and palliative home care, as well as catastrophic drug coverage. More important, a new public watchdog agency — the Canada Health Council - was set up to report on progress.

The federal government evidently believes these initiatives provide leverage. The argument is that, since federal funds support medicare, Ottawa has the right to demand an accounting for how they are used. Pettigrew apparently intends to expand dramatically the federal role from mere purchaser of services to central overseer of health care delivery.

This is a colossal gamble. The courts may well find such a strategy unconstitutional, in which case previous crises will pale in comparison. The provinces, of course, resent this manoeuvre, which is why Alberta and British Columbia have expressed reservations about the new Health Council. A Charter challenge seems inevitable.

The outcome may rest on how Ottawa uses its new power of oversight. Constitutional law is still a blank page in this field, and necessity is a powerful defence if federal authorities argue the need for fiscal discipline. Regrettably, fiscal discipline is not what Ottawa has in mind. In a recent speech to the Empire Club, Paul Martin indicated that any reform of medicare must include a "national pharmaceuticals strategy." He also proposed a national home care program and a new community care services package. In his own speech, Pettigrew added improved access to diagnostic procedures and shorter wait times for surgery to the shopping list.

It seems that Ottawa's objection to the term "medically necessary" is not that it is too broad, but that it is not broad enough. For those concerned with sustainability, this is disastrous though hardly unexpected news. Federal politicians believe they gain no credit for the day-to-day workings of the health system. The best way to get attention is to announce new services.

No doubt anticipating a reaction, Pettigrew listed ways the provinces could find savings: hire more nurse practitioners, expand "knowledge transfer," reform primary care, and so on. Whether any of these well-worn remedies will save a nickel is debatable: they certainly have not so far.

What is not debatable is that Paul Martin means to campaign for re-election on a promise to expand medicare. And while some new money will be available, it will not cover openended entitlements like a national home care program. The federal government intends to use its new oversight powers to make the provinces eat the difference - not a very wholesome prospect.

\section{Lawrie McFarlane}

Victoria, BC

Lawrie McFarlane was a deputy minister of health in British Columbia and CEO of Saskatchewan's first regional health authority. He writes on public policy.

\section{References}

1. McFarlane L, Prado CG. The bestlaid plans. Montréal and Kingston: McGill-Queen's University Press; 2003.

2. Cameron v. Nova Scotia (AG). 1999 NSJ 297 (NS CA).

3. Chaoulli and Zeliotis v. Attorney General of Quebec and Attorney General of Canada, Quebec Superior Court; 2000.

4. Auton v. BC (Minister of Health). 2000 BCSC 1142 (BC SC)

5. Pettigrew P. A renewed partnership for health care sustainability in Canada [speech to the Health Policy Summit 2004: Moving Healthcare Forward in Canada]. Toronto; 2004; Apr 20.

6. Martin P. Address to the Empire Club and Canadian Club. Toronto: 2004; Apr 16. 